\title{
Ethics in the Medical Practice of Non-Psychiatrist Doctors at the Marrakech University Hospital

\author{
Maryam Abrache ${ }^{1 *}$, Fatima Ezzahra Chekkouri ${ }^{1}$, Sara Ennazk ${ }^{1}$, Fatiha Manoudi ${ }^{1}$
}

\author{
${ }^{1}$ Mental Health Research Team, Ibn Nafis Psychiatric Hospital, Mohamed VI University Hospital, Marrakesh, Morocco \\ DOI: $10.36347 /$ sasjm.2021.v07i04.002 \\ | Received: 04.03.2021 | Accepted: 12.04.2021 | Published: 17.04.2021 \\ *Corresponding author: Maryam Abrache
}

Abstract

Original Research Article

Introduction: Ethics is an integral part of medical practice; medical ethics are based on the following principles: respect for the person, the principle of beneficence, the principle of non-maleficence and the principle of justice. We conducted a study that the objective is to study the perception of the notion of medical ethics, to assess the level of training and knowledge, to evaluate attitudes and practices in the exercise of the medical profession. Materials and methods: 100 doctors at the Marrakech University Hospital were recruited for a study about "Ethics in the medical practice of non-psychiatrist doctors", throughout 6-month and we completed a pre-designed, structured, anonymous questionnaire that describes the sociodemographic characteristics of the doctor and assesses and provides information on his knowledge, attitudes and practices in medical ethics. Results: The majority of physicians were aware of medical ethics and the majority had acquired knowledge in this area at the faculty level, It was also found that more than half of doctors were unaware of the existence of a code of ethics in Morocco and that most of the opinions were in favor of the establishment of a unit of information, education and communication in ethics of care and medical ethics; on the other hand, the majority of our doctors have deemed that the consent of patients is necessary during surgical treatments in the first place, followed by medical treatments. 35\% of physicians still always shared information with their patients in daily practice. Conclusion: These attitudes and practices are statically independent of the physician's medical or surgical specialty. Rather, they relate to the education of physicians in clinical ethics.

Keywords:_Ethical knowledge, deontology, medical decision, patient's consent, morals

Copyright $(\mathcal{O} 2021$ The Author(s): This is an open-access article distributed under the terms of the Creative Commons Attribution 4.0 International License (CC BY-NC 4.0) which permits unrestricted use, distribution, and reproduction in any medium for non-commercial use provided the original author and source are credited.

\section{INTRODUCTION}

Ethics and morality had the same meaning for a long time. They both have a similar etymology, one Greek and the other Latin. They both refer to manners [1]. Morality is based on a set of rules and principles of good conduct that requires doing good and avoiding evil [2]. Ethics is taken from the Greek word 'ethos', which means morals, the conduct of life and rules of behavior. It has the same etymology as the moral word [1]. Ethics and medical ethics are derived from the concepts of Aristotle and Hippocrates, the latter who considers that the doctor must commit himself to his teachers and their children, and to the sick to always seek good [3]. The ethical codes address the concept of fiduciary duty and the division of responsibilities between physicians, patients and society [4].

\section{METHODS}

This is a 6-month cross-sectional descriptive study (July 2018 - December 2018), covering a series of 100 physicians at the Mohammed VI University Hospital in Marrakech.

Our sample included doctors who were professors, attached doctors or residents at the Mohammed VI University Hospital in Marrakech. Anyone approached and informed who did not wish to participate in the study was not included in this study.

The evaluation of the participants was carried out using a previously designed anonymous structured questionnaire, which describes the socio-demographic characteristics of the physician, assesses the physician's knowledge of medical ethics and provides information on the physician's attitudes and practices in medical ethics.

Data analysis was performed with SPSS Statistics Software version 23.0. 


\section{RESULTS}

Our sample consisted of 100 physicians (51 women and 49 men). The most dominant age group was
25-34 years $(80 \%)$. $85 \%$ of them were resident physicians, $50 \%$ of whom were in a medical specialty and the other half in a surgical specialty (Table 1).

Table-1: Sociodemographic characteristics of the study population

\begin{tabular}{|l|l|l|}
\hline & Workforce & Percentage \\
\hline Age: & & $3 \%$ \\
Less than 25 years & 3 & $80 \%$ \\
25 - 34 years & 80 & $13 \%$ \\
35 - 44 years & 13 & $4 \%$ \\
45 - 55 years & 4 & $0 \%$ \\
Over 55 years & 0 & \\
\hline Gender : & & $49 \%$ \\
Female & 49 & $51 \%$ \\
Male & 51 & \\
\hline Rank: & & $11 \%$ \\
Professor & 11 & $4 \%$ \\
Attached Physician & 4 & $85 \%$ \\
Resident & 85 & $27 \%$ \\
\hline Year of Residence: & & $19 \%$ \\
Resident 1st year & 23 & $35 \%$ \\
Resident 2nd year & 16 & $14 \%$ \\
Resident 3rd year & 30 & $5 \%$ \\
Resident 4th year & 12 & \\
Resident 5th year & 4 & $79 \%$ \\
\hline Seniority: & & $13 \%$ \\
Less than 5 years & 79 & $8 \%$ \\
5 - 10 years & 13 & $50 \%$ \\
Over 10 years & 8 & \\
\hline Specialty: & & \\
Medical & 50 & \\
Surgical & 50 & \\
\hline
\end{tabular}

The majority of physicians were familiar with medical ethics (99\%) and the majority had acquired medical ethics knowledge at the faculty level (64\%). $68 \%$ of doctors had received training in the field of medical ethics during the university course and despite this training $60 \%$ of them were unaware of the principles of medical ethics. The majority of our subjects, $86 \%$ had never received medical ethics training during their professional practice and it was found in our study that $56 \%$ of doctors were unaware of the existence of a code of ethics and ethics in Morocco. We noted that $73 \%$ of subjects who were aware of the existence of a code of ethics did not know where to obtain it. In our study, $40 \%$ of subjects said they knew the principles of medical ethics while $60 \%$ of subjects said they did not. $68 \%$ of doctors were unaware of the existence of ethics committees in Morocco and only a quarter of the population studied knew that an ethics committee exists within the CHU of Marrakech. Regarding the establishment of information, education and communication unit, most doctors $(96 \%)$ had a favorable opinion.

The doctors felt that the consent of the patients is necessary during surgical treatments first, followed by medical treatments and then the paraclinical examinations and finally the clinical examination and interrogation. $35 \%$ of physicians still always shared information with their patients.

\section{DISCUSSION}

The most representative age group in the Blaise [5] series was 25-34 years old, which is similar to the data in our study. Our study, as well as data from the series conducted by the "Fédération des médecins omnipraticiens du Québec" [6], the Nguekeu series [7] and the Cella series [8], report a male predominance that appears as a rule in the literature. The series of Hariharan et al. [9], reported that $47 \%$ of responders were doctors while $53 \%$ were nurses and, in the Jalal et al. [10] study, all responders were doctors. In the Medscape survey [11, 12], $21 \%$ of physicians were generalists, while in our study, $100 \%$ of physicians were specialists. Brogen et al. [13] and the majority of the studies found that most physicians had already heard about medical ethics. In a study by Walrond et al. [14], the majority of participants $(60 \%)$ responded that they had acquired their knowledge of ethics during their medical training, which is also consistent with our study. Keeling's series [15] showed that $26.3 \%$ of the subjects in the study had not received training during the university course; this result is very close to our study, on the other hand, in the series of Janakiram et al. 
[16], $68 \%$ of subjects had not received training in the field of ethics during their medical studies. In the study of $\mathrm{Su}$ et al. [17], 52\% of practitioners had not received training in the field of ethics during professional practice; this figure was lower compared to our study. In the Blaise series [5] $60.6 \%$ of subjects knew that a code of ethics exists, while in our series the percentage was lower. In each of the studies of Nguekeu [7] and Eilts-Köchling [18], a representative part of the responders did not know the principles of medical ethics; in our study also more than half of our doctors were unaware of these principles. In the Blaise series [5], $80.5 \%$ were unaware of the existence of ethics committees; this percentage is somewhat similar to that found in our study. According to Salathé et al. [19], only $18 \%$ reported having an ethics committee. The series of Chaudhuri et al. [20] found that $67 \%$ of the population studied already knew that an ethics committee exists within their structure, whereas only $25 \%$ of our subjects knew it.

In the Blaise study [5], 54\% of caregivers obtained voluntary and informed consent from patients before providing care, and $92,2 \%$ first explained to the patient the act they were about to perform and obtained his consent before administering care. In our study, physicians found consent necessary during surgical treatments in the first place. In the study by Iezzoni et al. [21], the majority of practitioners $(88.7 \%)$ informed their patients about the benefits and risks of treatment or intervention. The study by Blaise [5], showed that $83 \%$ of participants used to give patients information about their disease. In our study, 35\% of doctors still shared information with their patients.

\section{CONCLUSION}

When a doctor looks after a patient, it is believed that he gives him a favor, on the contrary, according to medical ethics, it is the caregiver who becomes the obligation of the patient when the latter goes to a doctor to entrust his life or his health to him. Medical ethics do not have a definitive definition; it evolves, with medical knowledge, situations and techniques. The best guarantee of the patient's quality of care and freedom is based on respect for medical ethics. Health professionals may refer to the values of medical ethics in the event of a conflict or ethical problems. The values of medical ethics include respect for non-maleficence, charity, autonomy and justice; they enable health professionals and families to create a treatment plan and achieve the same common goal.

\section{REFERENCES}

1. Durand G. La bioéthique: nature, principes, enjeux: Les Editions Fides; 1997: 16.

2. Gueibe R. Droit, déontologie, morale et éthique. Kaïros. 2008;32:1.

3. Delassus E. Actualité du serment d'Hippocrate ; 2009.
4. MacDougall H, Langley GR. Medical ethics: Past, present and future. Retrieved April. 2013;18:2013.

5. Blaise MMP. Connaissances, attitudes et pratiques liees a l'ethique des soins et a la deontologie medicale chez les etudiants et aidants soignants des chu du mali; 2009.

6. des médecins omnipraticiens du Québec F. Sondage sur la perception qu'ont les médecins omnipraticiens de l'euthanasie. Homme. 2009;53:580.

7. Nguekeu SYN. Connaissance, attitude et pratique des personnels soignant sur l'éthique clinique et la bioéthique. Cas de l'hôpital général de Katudu; 2012.

8. Cella A. L'éthique médicale dans la pratique du médecin généraliste: identification des conflits éthiques et de l'utilité d'une aide. Enquête descriptive auprès des médecins généralistes de la région Midi-Pyrénées: Université Toulouse III-Paul Sabatier; 2015.

9. Hariharan S, Jonnalagadda R, Walrond E, Moseley $\mathrm{H}$. Knowledge, attitudes and practice of healthcare ethics and law among doctors and nurses in Barbados. BMC Medical ethics. 2006;7:7.

10. Jalal S, Imran M, Mashood A, Younis M. Awareness about Knowledge, Attitude and Practice of Medical Ethics pertaining to Patient Care, among Male and Female Physicians Working in a Public Sector Hospital of Karachi, Pakistan-A Cross-Sectional Survey. European Journal of Environment and Public Health. 2018;2:04.

11. Sondage : les médecins français et l'éthique médicale. Medscape; 2015. Disponible sur: http://francais.medscape.com/public/ethique.

12. Sondage : Les dilemmes éthiques des médecins français. Medscape; 2017. Disponible sur: https://francais.medscape.com/features/diaporama/ 33000134.

13. Akoijam Brogen S, Rajkumari B, Laishram J, Joy A. Knowledge and attitudes of doctors on medical ethics in a teaching hospital, Manipur. Age (years). 2009; 35:35.

14. Walrond E, Jonnalagadda R, Hariharan S, Moseley H. Knowledge, attitudes and practice of medical students at the Cave Hill Campus in relation to ethics and law in healthcare. West indian medical journal. 2006;55:42.

15. Keeling M. Centre de collaboration nationale sur les politiques publiques et la santé.

16. Janakiram C, Gardens SJ. Knowledge, attitudes and practices related to healthcare ethics among medical and dental postgraduate students in south India. 2014; 11:99-104.

17. Su L, Huang J, Yang W, Li H, Shen Y, Xu Y. Ethics, patient rights and staff attitudes in Shanghai's psychiatric hospitals. BMC medical ethics. 2012; 13:8.

18. Eilts-Köchling K, Heinze C, Schattner P, Voß M, Dassen T. Knowledge of professional codes of 
ethics among nursing professionals. Pflege. 2000;13:42-6.

19. Salathé M, Leuthold M, Amstad H, Vallotton M. Les comités d'éthique clinique en Suisse-un état des lieux. Correspondance. 2002; 14:295-7.

20. Chaudhuri A, Ray K, Biswas A B. Institutional ethics committee: a perspective of medical teachers of west Bengal. World journal of pharmaceutical and medical research. 2016.

21. Iezzoni LI, Rao SR, DesRoches CM, Vogeli C, Campbell EG. Survey shows that at least some physicians are not always open or honest with patients. Health Affairs. 2012; 31:383-91. 